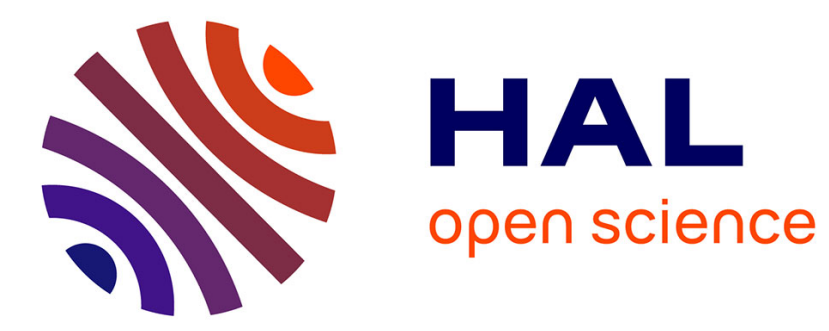

\title{
Rapid ascent of rhyolitic magma at Chaitén volcano, Chile
}

\author{
Jonathan M. Castro, Donald B. Dingwell
}

\section{To cite this version:}

Jonathan M. Castro, Donald B. Dingwell. Rapid ascent of rhyolitic magma at Chaitén volcano, Chile. Nature, 2009, 461 (8 octobre), pp.780-784. 10.1038/nature08458 . insu-00423346

\section{HAL Id: insu-00423346 https://hal-insu.archives-ouvertes.fr/insu-00423346}

Submitted on 8 Feb 2013

HAL is a multi-disciplinary open access archive for the deposit and dissemination of scientific research documents, whether they are published or not. The documents may come from teaching and research institutions in France or abroad, or from public or private research centers.
L'archive ouverte pluridisciplinaire HAL, est destinée au dépôt et à la diffusion de documents scientifiques de niveau recherche, publiés ou non, émanant des établissements d'enseignement et de recherche français ou étrangers, des laboratoires publics ou privés. 


\title{
Rapid ascent of rhyolitic magma at Chaitén volcano, Chile
}

\author{
Jonathan M. Castro ${ }^{1} \&$ Donald B. Dingwell ${ }^{2}$
}

1. Centre National de la Recherche Scientifique (CNRS), Institut National des Sciences de I'Univers (INSU), Université d'Orléans, Université François Rabelais-Tours, Institut des Sciences de la Terre d'Orléans, UMR 6113, Campus Géosciences, 1A Rue de la Férollerie, 45071 Orléans cedex 2, France

2. Department of Earth and Environmental Sciences, Ludwig-Maximillians Universitaet, 80333 Muenchen, Germany

\begin{abstract}
Rhyolite magma has fuelled some of the Earth's largest explosive volcanic eruptions $^{1}$. Our understanding of these events is incomplete, however, owing to the previous lack of directly observed eruptions. Chaitén volcano, in Chile's northern Patagonia, erupted rhyolite magma unexpectedly and explosively on 1 May 2008 (ref. 2). Chaitén residents felt earthquakes about 24 hours before ash fell in their town and the eruption escalated into a Plinian column. Although such brief seismic forewarning of a major explosive basaltic eruption has been documented $\underline{3}$, it is unprecedented for silicic magmas. As precursory volcanic unrest relates to magma migration from the storage region to the surface, the very short pre-eruptive warning at Chaitén probably reflects very rapid magma ascent through the sub-volcanic system. Here we present petrological and experimental data that indicate that the hydrous rhyolite magma at Chaitén ascended very rapidly, with velocities of the order of one metre per second. Such rapid ascent implies a transit time from storage depths greater than five kilometres to the near surface in about four hours. This result has implications for hazard mitigation because the rapidity of ascending rhyolite means that future eruptions may provide little warning.
\end{abstract}

Geophysical precursors to volcanic eruptions, such as volcano-tectonic earthquakes, tremor and deformation, all reflect magma migration beneath the volcano as the magma develops an ascent path ${ }^{4,5}$. Such signals are crucial for volcano monitoring, and increasingly, as the source mechanisms of seismicity are identified, eruption forecasting ${ }^{6}$ $7,8,9$. A critical unknown that has limited the accuracy of eruption forecasting is the rate of magma rise before an explosive eruption: this parameter controls not only degassing behaviour and flow rheology 10,11 , but also the timescale of accompanying precursory unrest and pre-eruptive warning ${ }^{12}$. A vast majority of andesite and dacite volcanic eruptions were preceded by weeks to months of precursory unrest, consistent with long magma ascent times and correspondingly sluggish (some centimetres per second) rise velocities $\frac{13}{}$. This pattern was broken on 1 May 2008 when Chaitén volcano, Chile, erupted with almost no warning at all. This explosive rhyolite eruption, the first ever to be scientifically monitored ${ }^{2}$, provides a unique opportunity to assess the conditions of pre-eruptive magma storage and ascent at rhyolite volcanoes. Of particular interest is the extreme suddenness of the eruption, because this implies that rhyolite is highly mobile in the shallow crust. Here we constrain the storage conditions and pre-eruptive ascent velocity of rhyolite magma at Chaitén by experimentally reproducing key mineralogical and textural characteristics of pumice erupted from the volcano.

Pre-eruptive unrest at Chaitén began on 30 April 2008 at about 20:00 h Chilean Local Time (CLT) when residents of Chaitén town, about $10 \mathrm{~km}$ southwest of the volcano, felt earthquakes strong enough to knock objects off shelves. They first observed ash fall in their town on 1 May 2008 at roughly 21:00 h (CLT). Seismic activity continued through to 2 May 2008 when a large explosion and Plinian eruption column tore through a prehistoric obsidian dome in the Chaitén caldera. After a week of fluctuating Plinian and sub-Plinian activity, a new lava dome began to grow, and this activity is still continuing. The Plinian eruption plume distributed a broad swath of tephra throughout the Andes $\frac{14}{}$. 
We collected samples of this ash blanket from two sites located about $10 \mathrm{~km}$ eastsoutheast of the vent, and at another about $2 \mathrm{~km}$ north of the vent. The tephra deposit comprises ash $(\sim 80 \%$ by volume), pumice lapilli and bombs $(\sim 17 \%)$, and obsidian fragments $(\sim 3 \%)$.

The pumice lapilli are rhyolitic in composition (Table 1 ) and nearly aphyric ( $<1$ vol.\% crystals). Crystals comprise both microphenocrysts $(0.5-1.0 \mathrm{~mm})$ and sparse microlites $(<100 \mu \mathrm{m})$, which we identified as plagioclase and biotite in about $10 \%$ of the sampled $(n=40)$ pyroclasts. The microphenocryst mineral population comprises plagioclase, $\mathrm{Fe}-\mathrm{Ti}$ oxides, orthopyroxene and biotite; however, many pumices are completely devoid of biotite. 
Table 1. Representative compositions of the Chaitén pumice and microphenocryst mineral phases.

\begin{tabular}{|c|c|c|c|c|c|c|c|}
\hline $\begin{array}{l}\text { Compon } \\
\text { ent }\end{array}$ & $\begin{array}{l}\text { Matrix } \\
\text { glass }^{ \pm}\end{array}$ & Bulk ${ }^{\ddagger}$ & $\begin{array}{c}\text { Glass } \\
\text { inclusio } \\
\text { ns }^{ \pm}\end{array}$ & $\begin{array}{l}\text { Plagiocla } \\
\text { se }^{ \pm}\end{array}$ & $\begin{array}{l}\text { Magnet } \\
\text { ite }\end{array}$ & $\begin{array}{l}\text { Ilmen } \\
\text { ite }\end{array}$ & $\begin{array}{l}\text { Orthopyrox } \\
\text { ene }^{ \pm}\end{array}$ \\
\hline \multicolumn{8}{|c|}{$\begin{array}{l}\text { †EPMA; } \neq \text { Bulk pumice } X-\text { ray fluorescence analysis. } \\
\text { n.d: not detected. An:Ab:Or }=58: 40: 02\end{array}$} \\
\hline Sample & $\begin{array}{c}\mathrm{Ch}-1- \\
08\end{array}$ & $\begin{array}{c}\text { Ch-1- } \\
08\end{array}$ & Ch-inc-1 & $\begin{array}{l}\text { Ch-plg2- } \\
08\end{array}$ & C1-grn1 & $\begin{array}{l}\text { C1- } \\
\text { grn2 }\end{array}$ & Ch-opx1-08 \\
\hline$n$ & $n=76$ & $n=5$ & $n=10$ & $n=20$ & $n=9$ & $n=9$ & $n=15$ \\
\hline $\mathrm{SiO}_{2}$ & $\begin{array}{l}76.1(0 \\
.5)\end{array}$ & $\begin{array}{l}75.6(0 \\
.4)\end{array}$ & $\begin{array}{l}76.1(0 . \\
3)\end{array}$ & $\begin{array}{c}59.2(0.3 \\
)\end{array}$ & n.d. & n.d. & $48.3(0.5)$ \\
\hline $\mathrm{Al}_{2} \mathrm{O}_{3}$ & $\begin{array}{l}13.7 \\
(0.2)\end{array}$ & $\begin{array}{l}13.9 \\
(0.2)\end{array}$ & $\begin{array}{l}13.0 \\
(0.4)\end{array}$ & $\begin{array}{l}26.1 \\
(0.5)\end{array}$ & $\begin{array}{l}2.57 \\
(0.05)\end{array}$ & $\begin{array}{l}0.17 \\
(0.01)\end{array}$ & $1.69(0.2)$ \\
\hline $\mathrm{TiO}_{2}$ & $\begin{array}{c}0.13 \\
(0.01)\end{array}$ & $\begin{array}{c}0.14 \\
(0.03)\end{array}$ & $0.5(0.1)$ & n.d. & $\begin{array}{c}8.7 \\
(0.07)\end{array}$ & $\begin{array}{l}45.6 \\
(0.19)\end{array}$ & $0.13(0.02)$ \\
\hline $\mathrm{Fe}_{2} \mathrm{O}_{3}$ & $\begin{array}{l}1.27 \\
(0.1)\end{array}$ & $\begin{array}{c}1.5 \\
(0.02)\end{array}$ & $\begin{array}{c}1.42 \\
(0.01)\end{array}$ & $\begin{array}{c}0.16 \\
(0.03)\end{array}$ & $\begin{array}{c}90.3 \\
(0.34)\end{array}$ & $\begin{array}{c}54.6 \\
(0.39)\end{array}$ & $31.2(1.4)$ \\
\hline $\mathrm{MgO}$ & $\begin{array}{c}0.28 \\
(0.01)\end{array}$ & $\begin{array}{l}0.26 \\
(0.1)\end{array}$ & $\begin{array}{c}0.29 \\
(0.02)\end{array}$ & n.d. & $\begin{array}{c}0.91 \\
(0.03)\end{array}$ & $\begin{array}{c}1.80 \\
(0.04)\end{array}$ & $16.6(0.3)$ \\
\hline MnO & $\begin{array}{c}0.06 \\
(0.01)\end{array}$ & $\begin{array}{c}0.05 \\
(0.01)\end{array}$ & $\begin{array}{c}0.06 \\
(0.03)\end{array}$ & n.d. & $\begin{array}{c}0.54 \\
(0.04)\end{array}$ & $\begin{array}{c}0.86 \\
(0.04)\end{array}$ & $1.79(0.2)$ \\
\hline $\mathrm{Cr}_{2} \mathrm{O}_{3}$ & n.d. & n.d. & n.d. & n.d. & $\begin{array}{c}0.02 \\
(0.02)\end{array}$ & $\begin{array}{c}0.02 \\
(0.01)\end{array}$ & n.d. \\
\hline $\mathrm{CaO}$ & $\begin{array}{c}1.41 \\
(0.01)\end{array}$ & $\begin{array}{c}1.46 \\
(0.02)\end{array}$ & $\begin{array}{l}1.10 \\
(0.03)\end{array}$ & $\begin{array}{l}8.13 \\
(0.2)\end{array}$ & n.d. & n.d. & $0.34(0.03)$ \\
\hline $\mathrm{Na}_{2} \mathrm{O}$ & $\begin{array}{l}4.00 \\
(0.1)\end{array}$ & $\begin{array}{c}4.04 \\
(0.02)\end{array}$ & $\begin{array}{l}3.91 \\
(0.2)\end{array}$ & $\begin{array}{c}6.5 \\
(0.06)\end{array}$ & n.d. & n.d. & n.d. \\
\hline $\mathrm{K}_{2} \mathrm{O}$ & $\begin{array}{c}2.98 \\
(0.04)\end{array}$ & $\begin{array}{l}2.93 \\
(0.05)\end{array}$ & $\begin{array}{l}3.10 \\
(0.1)\end{array}$ & $\begin{array}{c}0.28 \\
(0.02)\end{array}$ & n.d. & n.d. & n.d. \\
\hline $\mathrm{P}_{2} \mathrm{O}_{5}$ & $\begin{array}{c}0.04 \\
(0.03)\end{array}$ & $\begin{array}{c}0.06 \\
(0.01)\end{array}$ & 0.01 & n.d. & n.d. & n.d. & n.d. \\
\hline $\begin{array}{l}\mathrm{SO}_{2} \\
\text { (p.p.m.) }\end{array}$ & 31 (15) & n.d. & 500 & n.d. & n.d. & n.d. & n.d. \\
\hline $\begin{array}{l}\mathrm{Cl}^{-} \\
\text {(p.p.m.) }\end{array}$ & $\begin{array}{l}925 \\
(66)\end{array}$ & n.d. & 3550 & n.d. & n.d. & n.d. & n.d. \\
\hline Total & $\begin{array}{l}100.0 \\
(0.45)\end{array}$ & $\begin{array}{c}99.9 \\
(0.77)\end{array}$ & $\begin{array}{c}99.5 \\
(1.02)\end{array}$ & $\begin{array}{l}100.4 \\
(0.53)\end{array}$ & $\begin{array}{l}103.0 \\
(0.34)\end{array}$ & $\begin{array}{l}103.0 \\
(0.44)\end{array}$ & $100.1(0.40)$ \\
\hline
\end{tabular}


Plagioclase compositions are relatively uniform $\left(\sim A n_{40-45}\right)$, aside from a few crystal cores as calcic as $\mathrm{An}_{68}$. These microphenocrysts are invariably rounded with zoning patterns (Fig. 1b) characterized by jagged compositional boundaries, indicating several cycles of dissolution and growth ${ }^{15}$. The lack of euhedral overgrowth rims on these plagioclase microphenocrysts suggests that they were in a state of resorption before eruption.

Orthopyroxene is euhedral, and has a restricted compositional range $\left(\mathrm{En}_{50-55}\right.$; Table 1$)$. $\mathrm{Fe}-\mathrm{Ti}$ oxides include both titanomagnetite and rare ilmenite. We did not obtain reliable compositional analyses of biotite owing to its small size (1-2 m wide).

Figure 1: Backscattered electron micrographs of Chaitén pumice pyroclasts.

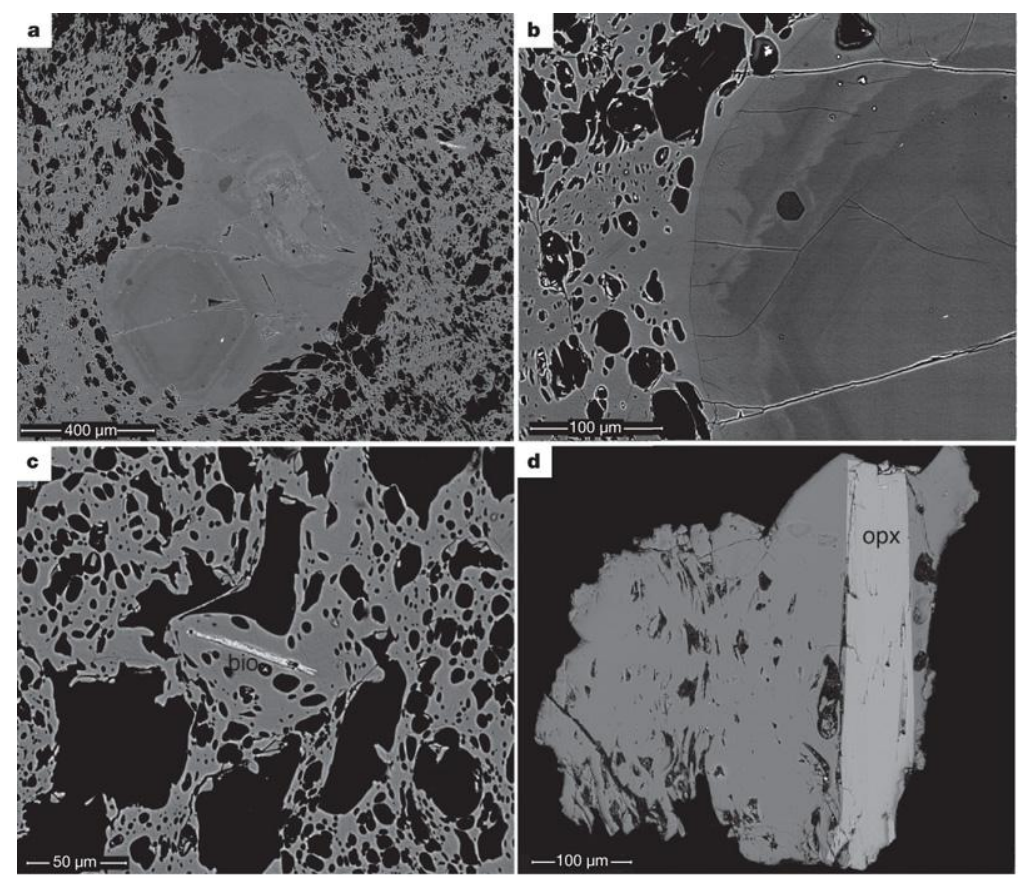

a, Plinian pumice with a plagioclase microphenocryst set within microlite-free vesicular glass. b, Close-up view of the lower right side of the microphenocryst in a. Zones of different grey-value comprise oscillatory zoning in which the anorthite content varies from about $\mathrm{An}_{40}$ in dark-grey zones to about $\mathrm{An}_{45}$ in brighter regions. The dark grey blob at the centre is a hydrous rhyolite glass inclusion. c, Plinian pumice with biotite microlite at the grain centre. d, Plinian pumice pyroclast fragment with an orthopyroxene microphenocryst (light-grey elongate).

Plagioclase and orthopyroxene microphenocrysts contain abundant small $(<50 \mu \mathrm{m})$ rhyolitic glass inclusions (Fig. 1 ; Table 1 ). These inclusions contain large vesicles $(>20 \mu$ $\mathrm{m}$ ) that could reflect the entrapment of volatile-saturated melt during crystal growth. The dominant volatile component of the glass is water $\left(\mathrm{H}_{2} \mathrm{O}\right.$ and $\left.\mathrm{OH}^{-}\right)$, and the concentrations $(\sim 1.3$ to $2.3 \mathrm{wt} \%)$ could reflect pre and syn-eruptive degassing through cracks and cleavage planes (Supplementary Information). The glass inclusions contain no detectable $\mathrm{CO}_{2}$ (detection limit $\sim 10$ p.p.m.).

Obsidian pyroclasts are mineralogically identical to the pumice; however, they contain larger plagioclase crystals $(2-3 \mathrm{~mm})$ and are generally more crystalline ( $\sim 2-5$ vol.\%). The obsidians are low in $\mathrm{H}_{2} \mathrm{O}$ (0.5-1 wt\%; Supplementary Information) and devoid of $\mathrm{CO}_{2}$. It is not possible to prove that the obsidian pyroclasts are juvenile or lithic fragments derived from the obsidian dome in the Chaitén caldera, because this prehistoric lava dome is compositionally indistinguishable from the new magma ${ }^{16}$. We therefore focus the rest of this analysis and discussion on the petrogenesis of the Chaitén pumice, which is undoubtedly a juvenile eruption product. 
The crystal complement in the Chaitén rhyolite records key information about preeruptive magma storage and ascent, as characteristics of mineral phases are all functions of pressure $(P)$, temperature $(T)$ and the melt- $\mathrm{H}_{2} \mathrm{O}$ content. These intensive parameters may be constrained through petrological experiments ${ }^{17,18}$. One complication is that the plagioclase microphenocrysts appear to have been unstable in the melt before eruption, and as such could be xenocrystic. As we show below, with the exception of rare calcic cores, plagioclase compositions are compatible with the rhyolite melt over a range of $\mathrm{P}_{\mathrm{H}_{2} \mathrm{O}-\mathrm{T}}$ space. Furthermore, the abundance of glass inclusions in the microphenocrysts, whose major element compositions are identical to the pumice matrix glass, suggests that the plagioclase crystals are indeed primary.

We performed petrological experiments $\frac{18,19,20}{}$ on a powdered pumice pyroclast over a range of $P_{\mathrm{H}_{2} \mathrm{O}-T}$ conditions (Supplementary Information). Given the explosive nature of the eruption, and the lack of $\mathrm{CO}_{2}$ in melt inclusions, we assumed that the pre-eruption magma was water-saturated, and added just enough water to the pumice powder to achieve water-saturation. These experiments (Fig. 2) indicate that the crystal population is stable in hydrous rhyolite melt over a wide $P_{\mathrm{H}_{2} \mathrm{O}-T}$ range $(\sim 50-200 \mathrm{MPa} ; \sim 780-$ $850^{\circ} \mathrm{C}$ ). Permissible magma storage conditions may be further bracketed by considering that the natural plagioclase $\left(\sim \mathrm{An}_{40-45}\right)$ and orthopyroxene $\left(\sim \mathrm{En}_{50-55}\right)$ are together reproduced at about $T<825^{\circ} \mathrm{C}$ and $P>120 \mathrm{MPa}$. These conditions are consistent with temperatures calculated from compositions of titanomagnetite-ilmenite pairs in the pumice $\left(\sim 800 \pm 10^{\circ} \mathrm{C}\right)^{21}$. The pressure minimum (120 MPa) corresponds to a magma chamber depth of about $5 \mathrm{~km}( \pm 0.5 \mathrm{~km})$, assuming a range of country rock densities $\left(2,300-2,700 \mathrm{~kg} \mathrm{~m}^{-3}\right)$. Higher magma storage pressures may be warranted, as the presence of biotite in some samples implies $T<800^{\circ} \mathrm{C}$, and consequently higher $P_{\mathrm{H}_{2} \mathrm{O}}$, to stabilize plagioclase of the natural composition. Taking these observations into account, a range of magma storage conditions is possible in $P_{\mathrm{H}_{2} \mathrm{O}-T}$ space (Fig. 2).

Figure 2: $\mathrm{H}_{2} \mathrm{O}$-saturated phase relations in the Chaitén rhyolite.

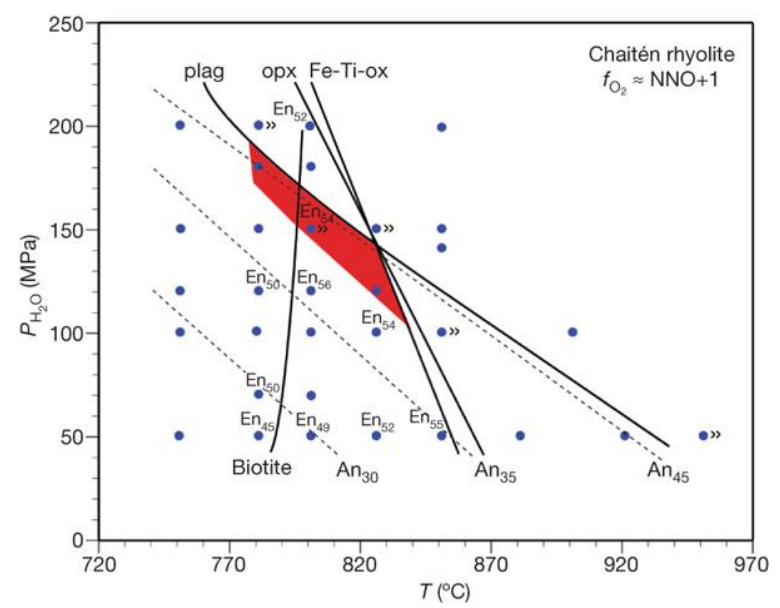

Mineral-in curves illustrate the stability limits of the natural microphenocryst minerals (plag, plagioclase; opx, orthopyroxene; Fe-Ti-ox, titanomagnetite). The symbol ' $\rangle /$ indicates 'reversal' experiments in which pre-annealed aliquots of crystal-rich material were subjected to higher temperature. Fine dashed lines are isopleths contouring the average An-content (mol.\%) in plagioclase microlites and overgrowth rims. The Encontents (mol.\%) are given for selected experiments. The red region demarcates a permissible magma storage $P_{\mathrm{H}_{2} \mathrm{O}-T}$ zone based on matching the experimental phase assemblage, mineral compositions, and crystallinity with those features observed in the Plinian pumice. $f_{\mathrm{O}_{2}}$, oxygen fugacity. 
All experiments conducted at $P_{\mathrm{H}_{2} \mathrm{O}}$ and/or a $T$ less than the inferred storage conditions grew abundant microlites ( $\sim 10-40$ vol.\%), in addition to euhedral overgrowth rims on plagioclase fragments over timescales of days (Supplementary Information). The nearly aphyric character of the natural pumice is in contrast to this, and therefore must indicate magma storage at near-liquidus conditions, and then very rapid ascent to the surface. That the plagioclase microphenocrysts remained rounded during magma ascent across a $P_{\mathrm{H}_{2} \mathrm{O}-T}$ space that should have promoted plagioclase crystallization (Fig. 2) indicates that Chaitén magma rose faster than some threshold rate that would have allowed plagioclase rim growth. To quantify this rate, we performed decompression experiments $\frac{22}{}$ along temperature isotherms that bracket the range of possible storage conditions (780 and $\left.825^{\circ} \mathrm{C}\right)$. The starting pressures $(200$ and $150 \mathrm{MPa}$ ) lie just above the plagioclase liquidus such that any microphenocryst fragments included in the annealed powder were partly resorbed before decompression. We equilibrated aliquots of the powdered pumice at the starting conditions for three days, and then decompressed charges to a final pressure of $30 \mathrm{MPa}$ in a series of $5 \mathrm{MPa}$ steps. The decompression intervals range from about 4 to $17 \mathrm{~h}$. The dwell periods (7.5-15 $\mathrm{min}$ ) between decompression steps define linear decompression rates of 10,20 and $40 \mathrm{MPa} \mathrm{h}^{-1}$.

Faceted plagioclase rims grew at 10 and $20 \mathrm{MPa} \mathrm{h}^{-1}$ at both 780 and $825^{\circ} \mathrm{C}$, but did not grow at $40 \mathrm{MPa} \mathrm{h}^{-1}$ in the $825^{\circ} \mathrm{C}$ experiment (Fig. 3). Very thin $(<3 \mu \mathrm{m})$, discontinuous rims grew in the $40 \mathrm{MPa} \mathrm{h}^{-1}, 780^{\circ} \mathrm{C}$ run, but these rims did not grow in a subsequent experiment at $50 \mathrm{MPa} \mathrm{h}^{-1}$. Therefore, the decompression rate that precludes the formation of plagioclase rims is similar at 780 and $825^{\circ} \mathrm{C}\left(\sim 40 \mathrm{MPa} \mathrm{h}^{-1}\right)$, and can be considered a minimum value for the Chaitén magma. This rate corresponds to an average ascent velocity of about $0.5 \mathrm{~m} \mathrm{~s}^{-1}$, considering a bubble-free magma overburden density of about $2,300 \mathrm{~kg} \mathrm{~m}^{-3}$.

\section{FIGURE 3. Montage of backscattered electron images collected on decompression experiments on the Chaitén pumice.}

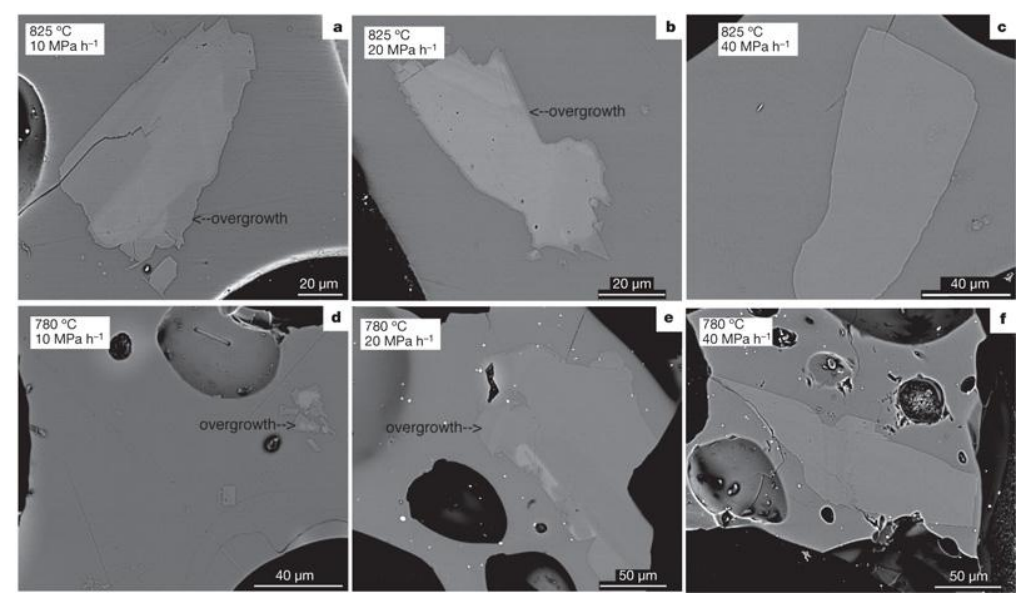

Each image shows one or more plagioclase microphenocrysts with an overgrowth of new plagioclase, appearing as a darker $\operatorname{rim}(\mathbf{a}, \mathbf{b}, \mathbf{d}, \mathbf{e})$ and without overgrowth $(\mathbf{c}, \mathbf{f})$. At $780^{\circ} \mathrm{C}$ and $825^{\circ} \mathrm{C}$, decompression rates higher than $20 \mathrm{MPa} \mathrm{h}^{-1}$ prevent the overgrowth of plagioclase owing to very short crystallization intervals. 
We note that the limiting decompression rates are within the viscous regime and are therefore consistent with intact magma ascent presaging the explosive failure at higher decompression rates ${ }^{23,24}$. In other words, the decompression history recorded in the pumice probably represents pre-fragmentation ascent. The ascent rate inferred from decompression experiments $\left(\sim 0.5 \mathrm{~m} \mathrm{~s}^{-1}\right)$ would correspond to strain rates ( = ascent rate/conduit radius; $r=10-100 \mathrm{~m}$ ) of about $10^{-1}$ to $10^{-3} \mathrm{~s}^{-1}$. The viscosity of the Chaitén magma over a range of temperature and water contents $\frac{25}{}\left(750-825^{\circ} \mathrm{C}, 1-4 \mathrm{wt} \% \mathrm{H}_{2} \mathrm{O}\right)$ is still at least one order of magnitude lower $\left(\sim 10^{6}-10^{8} \mathrm{~Pa} s\right)$ than the critical values required to cause a glassy response of the magma $\left(\sim 10^{9}-10^{10} \mathrm{~Pa} \mathrm{~s}\right)$ at the implied shear strain rates ${ }^{26}$. This result indicates that during much of its rise in the conduit, the chaitén magma would not have been capable of autobrecciating as a result of shear $\stackrel{27}{ }$, unlike silicic magma in its final stages of ascent in lava dome eruptions $\underline{\underline{8,9}}$.

Our results show for the first time that rhyolite magma can ascend very rapidly from depth $(>5 \mathrm{~km}$ ) before explosive fragmentation. The magma ascent timescale at Chaitén was brief $(\sim 4 \mathrm{~h})$, and shorter than the period of the felt seismic unrest ( $\sim 1$ day) that preceded the eruption. That the earthquake swarm duration exceeded the pre-eruptive ascent timescale may reflect preparatory fracturing and the formation of the magma's pathway to the surface $\frac{28}{}$, or perhaps the swarm was an eruption trigger. Nonetheless, the brevity of pre-eruptive magma rise at Chaitén is clear evidence that near-liquidus, hydrous rhyolite is very fluid and, in all likelihood, capable of creating and transiting a magma transport system ${ }^{29}$ on timescales that are difficult to prepare for, especially in the absence of monitoring instruments. Our findings therefore emphasize the need to monitor rhyolite volcanoes that have undergone Holocene rhyolitic activity. In more densely populated regions this would be essential to avoid a major volcanic disaster.

\section{Methods Summary}

Glass and mineral compositions were analysed using Cameca SX-100 and JEOL JXA8900R electron microprobes at the University of Munich and the Smithsonian Institution, respectively. Glasses were analysed with an accelerating voltage of $12-15 \mathrm{keV}$, a $10-$ $20 \mu \mathrm{m}$ beam, and $10 \mathrm{nA}$ beam current; mineral analyses used a 3-5 $\mu \mathrm{m}$ beam and the same acceleration voltage and current. Standardization was performed on quartz ( $\mathrm{Si}$ ), anorthite (Ca), bytownite (Al), corundum (Al), microcline (K), albite ( $\mathrm{Na})$, hornblende $(\mathrm{Fe}, \mathrm{Mg})$, ilmenite $(\mathrm{Ti}, \mathrm{Fe})$, and chromite $(\mathrm{Cr})$. Na was analysed first in all routines to minimize migration effects.

We analysed very small $(<10 \mu \mathrm{m})$ plagioclase and orthopyroxene microlites by quantitative EDS on a FEI field emission scanning electron microscope (SEM) at the Smithsonian Institution. Analytical conditions consisted of 10-12 keV, a beam current of 0.5-1 nanoamps, spot size of $\sim 1 \mu \mathrm{m}$, and $5 \mathrm{~mm}$ working distance. We calibrated the instrument against plagioclase, pyroxene, and glass standards the compositions of which were independently analysed by either electron probe microanalyser (EPMA) or wet chemistry. Reproducibility of the standard, experimental and natural mineral compositions with quantitative EDS was good, as reflected by errors of about $\pm 3.0 \mathrm{~mol} \%$ An and $\pm 5.0 \mathrm{~mol} \%$ En relative to the EPMA and wet chemical values.

The water contents of obsidian chips and glass inclusions were determined with synchrotron-source Fourier transform infrared (FTIR) spectroscopy at the Lawrence Berkeley National Laboratory Advanced Light Source, according to techniques described in ref. $\underline{30}$.

Hydrothermal phase equilibrium and decompression experiments were conducted in water-pressurized Waspaloy cold-seal vessels with nickel filler rods, according to methods described in refs $\underline{18}$ and $\underline{22}$. 


\section{References}

1. Wilson, C. J. N. \& Walker, G. P. L. The Taupo eruption, New Zealand. I. General aspects. Phil. Trans. R. Soc. Lond. A 314, 199-228 (1985)

2. Carn, S. et al. The unexpected awakening of Chaitén volcano, Chile. Eos 90, 205206 (2009)

3. Soosalu, H. \& Einarsson, P. Earthquake activity related to the 1991 eruption of the Hekla volcano, Iceland. Bull. Volcanol. 63, 536-544 (2002)

4. Kilburn, C. R. J. \& Voight, B. Slow rock fracture as eruption precursor at Soufriere Hills volcano, Montserrat. Geophys. Res. Lett. 25, 3665-3668 (1998)

5. Roman, D. C. \& Cashman, K. V. The origin of volcano-tectonic earthquake swarms. Geology 34, 457-460 (2006)

6. Chouet, B. Long-period volcano seismicity: its source and use in eruption forecasting. Nature 380, 309-316 (1996)

7. Voight, B. R. \& Cornelius, R. R. Prospects for eruption prediction in near real-time. Nature 350, 695-698 (1991)

8. Tuffen, H., Smith, R. \& Sammonds, P. Evidence for seismogenic fracture of silicic magma. Nature 253, 511-514 (2008)

9. Lavallée, Y. et al. Seismogenic lavas and explosive eruption forecasting. Nature 453, 507-510 (2008)

10. Gardner, J. E., Hilton, M. \& Carroll, M. R. Experimental constraints on degassing of magma: isothermal bubble growth during continuous decompression from high pressure. Earth Planet. Sci. Lett. 168, 201-218 (1999)

11. Llewellin, E. W. \& Manga, M. Bubble suspension rheology and implications for conduit flow. J. Volcanol. Geotherm. Res. 143, 205-217 (2005)

12. Kilburn, C. R. J. \& Sammonds, P. R. Maximum warning times for imminent volcanic eruptions. Geophys. Res. Lett. 32, L24313 (2005)

13. Rutherford, M. J. in Minerals Inclusions and Volcanic Processes (eds Putirka, K. D. \& Tepley, F. J.) 241-271 (Mineralogical Society of America, 2008)

14. Watt, S. et al. Fallout and distribution of volcanic ash over Argentina following the May 2008 explosive eruption of Chaitén, Chile. J. Geophys. Res. 114 B04207 doi:10.1029/2008JB006219 (2009)

15. Blundy, J., Cashman, K. \& Humphreys, M. Magma heating by decompressiondriven crystallization beneath andesite volcanoes. Nature 443, 76-80 (2006)

16. Naranjo, J. A. \& Stern, C. R. Holocene tephrochronology of the southernmost part $\left(42^{\circ} 30^{\prime}-45^{\circ} \mathrm{S}\right)$ of the Andean Southern Volcanic Zone. Rev. Geol. Chile 31, 291306 (2004)

17. Hammer, J. E. \& Rutherford, M. J. Petrologic indicators of pre-eruption magma dynamics. Geology 31, 79-82 (2003)

18. Coombs, M. L. \& Gardner, J. E. Shallow-storage conditions for the rhyolite of the 1912 eruption at Novarupta, Alaska. Geology 29, 775-778 (2001)

19. Hammer, J. E., Rutherford, M. J. \& Hildreth, W. Magma storage prior to the 1912 eruption at Novarupta, Alaska. Contrib. Mineral. Petrol. 144, 144-162 (2002)

20. Hammer, J. E. \& Rutherford, M. J. An experimental study of the kinetics of decompression-induced crystallization in silicic melt. J. Geophys. Res. 107 doi:10.1029//2001JB000281 (2002) 
21. Ghiorso, M. S. \& Evans, B. W. Thermodynamics of rhombohedral oxide solid solutions and a revision of the Fe-Ti two-oxide geothermometer and oxygenbarometer. Am. J. Sci. 308, 957-1039 (2008)

22. Castro, J. M. \& Gardner, J. E. Did magma ascent rate control the explosiveeffusive transition at the Inyo volcanic chain, CA? Geology 36, 279-282 (2008)

23. Papale, P. Strain-induced magma fragmentation in explosive eruptions. Nature 397, 425-428 (1999)

24. Dingwell, D. B. Volcanic dilemma: flow or blow? Science 273, 1054-1055 (1996)

25. Giordano, D., Russell, J. K. \& Dingwell, D. B. Viscosity of magmatic liquids: A model. Earth Planet. Sci. Lett. 271, 123-134 (2008)

26. Gonnermann, H. M. \& Manga, M. Explosive volcanism may not be an inevitable consequence of magma fragmentation. Nature 426, 432-435 (2003)

27. Tuffen, H., Dingwell, D. B. \& Pinkerton, H. Repeated fracture and healing of silicic magma generate flow banding and earthquakes? Geology 31, 1089-1092 (2003)

28. Smith, R., Kilburn, C. R. J. \& Sammonds, P. R. Rock fracture as a precursor to lava dome eruptions at Mount St. Helens from June 1980 to October 1986. Bull. Volcanol. 69, 681-693 (2007)

29. Scandone, R., Cashman, K. V. \& Malone, S. D. Magma supply, magma ascent and the style of volcanic eruptions. Earth Planet. Sci. Lett. 253, 513-529 (2007)

30. Castro, J. M. et al. Timescales of spherulite crystallization inferred from water concentration profiles. Am. Mineral. 93, 1816-1822 (2008)

31. Bacon, C. R. \& Hirschmann, M. M. Mg/Mn partitioning as a test for equilibrium between coexisting Fe-Ti oxides. Am. Mineral. 73, 57-61 (1988)

32. Silver, L. A., Ihinger, P. D. \& Stolper, E. The influence of bulk composition on the speciation of water in silicate glasses. Contrib. Mineral. Petrol. 104, 142-162 (1989) 